\title{
A Study of the Problems for Development of Technical and Vocational Education in Katsina State, Nigeria
}

\author{
Isah Usman, Dr. Che Kum Celement, Dr. Md. Abu Raihan \\ ${ }^{I}$ (M.Sc.T.E. student, TVE Department, IUT) \\ ${ }_{2}^{2}$ (Professor \& Head, TVE Department, IUT) \\ 3 (Assistant Professor, TVE Department, IUT,
}

\begin{abstract}
Technical and Vocational Education TVE is the type of education which proved to have impacts on productivity and economic development of many developed societies. The study was conducted in government approved Technical and Vocational Institutions in Katsina State, Nigeria. The aim was to investigate the problems for development of TVE in the State and suggest strategies for improvement. For convenience of data collection, five (5) Technical and Vocational Institutions in Katsina State were purposively taken as sample. The data was collected through questionnaire from the population which consists: Principals, Teachers and Workshop Attendants of the selected five 5 Institutions. The population was estimated to be 164 and $30 \%$ of this population was taken as sample, thus $(\mathrm{n}=50)$. Ten 10 questionnaires were administered in each institution. Thirty seven out of fifty 50 questionnaires were received which translate $74 \%$ rate of return. Chi-square Test and Weighted Average were used to analyze and interpret the data. It was found that, there are historical reasons that hinder the development of TVE in the country, there are inadequate equipment and facilities in Technical schools, there are less competent technical teachers; and inadequate fund allocation worsen the situation. Moreover, this study identifies the implications of these problems on the students and the trends in policymaking, planning and implementation of TVE programs. From the study it was recommended that, the government can assist in solving the problems of TVE by; assigning technical and vocational experts in designing and evaluating the technical and vocational schools curriculum; adding welfare and incentives for technical teacher; open more technical colleges; more vocational schools and create a separate ministry of technical and vocation education
\end{abstract}

Keywords: - TVE in Nigeria, Katsina State, Problems of TVE, Economic development

\section{Background:}

\section{INTRODUCTION}

In the twenty-first century, both developed and developing countries are characterized with rapid changes in a transition that is modeling the world into a "global village" full of competitions and interdependency. Major forces are driving change in the world of work. Recent development progress in education means there is more skilled workers need in the world than the available prospects (Tripney et al., 2012). Simultaneously, global unemployment is on the increase. Technical, Vocational Education and Training (TVET) remains the popular means by which trained manpower is produced for economic and industrial growth of both developed and developing countries. TVET is one of the manpower development programmes of study that is attracting the attention of various countries around the world (Edukugho, 2011; Muhammad, 2012). In defining Technical, Vocational Education and Training (TVET) in its National Policy on Education (2004), the Federal Republic of Nigeria stated that; "Technical and Vocational Education is used as comprehensive term referring to those aspects of educational process involving in addition to general education, the study of technologies and related sciences and acquisition of practical skills, attitudes, understanding and knowledge relating to occupations in the sectors of economic and social life" (Ibukun, 2010). This is in line with that of (UNESCO, 2005) definition of TVET. The technological expansion of a nation requires the significance and functional skills and competencies in the trade world. This was clearly stated in the national policy on education. The policy articulated the objectives of technical education in Nigeria, which include acquisition of appropriate skills, competencies and abilities that will provide trained manpower in applied sciences, technology and business particularly at craft, advanced craft and technical levels. Provide the technical knowledge and vocational skills necessary for agricultural, commercial and economic development. Giving training and impart the necessary skills to individuals thus, they will be self-reliant economically (FRN, 2004). Recent shocks provoked by the international financial crises exposed severe weaknesses within the global economic system which rapidly spread to the employment sector, triggering a global job crisis. The global economy has substantially reduced its capacity to add new jobs. Youth have been particularly hit hard by the economic crises. The youth unemployment rate rose sharply during this period, from 11.6 to 12.7 percent, and, in the absence of 
economic growth and development, this pattern is likely to continue (ILO, 2011). In 2011, 74.8 million youth aged 15-24 were unemployed; globally, young people are nearly three times as likely as adults to be unemployed (ILO, 2012). There is significant regional variation in youth unemployment. Countries of Middle East, Africa, South Asia and Latin America are particularly affected (UN, 2012; UN/DESA, 2011).

\section{The Historical Development of TVE in Nigeria:}

Technical and vocational education in Nigeria had a slow start and developed less quickly than other forms of education. This was partially due to the fact that the voluntary agencies (Missionaries) which pioneered Western education in Nigeria were unable to increase or popularize technical and vocational education on the same scale as literary education since the former is much more expensive in terms of staff and equipment. Moreover, the situation was further complicated by the fact that most of those British colonial policy-makers were literary men and women who had no knowledge of technical and vocational education (Fafunwa, 1974). Despite the indigenous apprenticeship system of vocational training, missionary schools which flourished then introduced Farming, Bricklaying and Carpentry as part of the curriculum. But those skills were not seriously regarded by both pupils and parents, the programmes did not sustain for too long except for the Blaize Memorial Industrial School in Abeokuta, founded by some Nigerians and West Indians, and then the Hope Waddel training Institute in Calabar established by the church, Missionary Society in 1895. (Henry, 2003). Technical and vocational education began as an organized sector of the educational system only in the late forties with the implementation of the programmes outlined in the ten-year development plan. The program was financed mainly from funds made available by the United Kingdom government under the colonial development and welfare scheme. Four types of institutions were created; technical institutes, trade centres, handicraft and domestic science centres. During the 1950's there was much debate as to what the exact form and content of Nigerian technical and vocational education ought to be, skill levels to be aims at, courses, curricular, and examination standards. There were recommendations to: (1). Provide a viable base upon which technical and vocational education could be built. (2). Provide a means for making the individual education more relevant to the contemporary Nigerian environment and its problems. The Ashby commission (1959) on which the subsequent development of technical and vocational education in 1960 s to date was based singled out the emphasis placed on literary education at the secondary and post-secondary levels in the Nigerian educational system. After Nigerian independence, technical and vocational education followed closely in the pattern developed by the British government (Osuala, 1981). The education system remained largely literary in nature with vocational and technical aspects not made popular. Dike, 2009 \& Kennedy, 2012 stated that despite the various attempts at the regional levels to initiate some new ideas and reforms by the Nigerian political leaders, the structure and aims remained largely literary and static.

\section{Condition and Prevailing Situation of TVE in Katsina State:}

Katsina state has the population of about 459,022 million peoples as estimated in 2007; but it has only one (1) Government Vocational School named as Youth Craft Village; four (4) Government Technical Colleges, named as GTC Mashi, Ingawa, Funtua \& Charanchi; one (1) Polytechnic Institute named as Hassan Usman Katsina Polytechnic and very few private own Vocational Centers. These colleges and vocational/craft centers are not sufficient for this population. Moreover, the schools especially the vocational and craft centers are reported to have small number of academic staffs and lack adequate workshop facilities (Alamu, 2011). It is in view of these, that efforts need to be made by the government and stakeholders to encourage and develop technical and vocational education in Katsina state for the economic development of the country.

Objectives of the Study: The focus of the study was to observe the problems for development of technical and vocational education in Katsina state, Nigeria and suggest strategies for improvement. The specific objectives of the study were to: (i) Discover the historical constraints for development of technical and vocational education in Nigeria; (ii) Examine if lack of equipment and facilities are the problems for development of technical and vocational education in Katsina state; (iii) Identify whether inadequate and incompetent technical teachers are the major problems for TVE development in Katsina State; (iv) Discover the effects of TVE problems on students; (v) Identify the problems related to the trends in Policymaking, Planning \& Implementation of TVE Programmes; (vi) Recommend the necessary measures that government could take to solve the problems of TVE.

\section{Significance of the Study:}

It is expected that the results of this study will make significant contribution to the effective development of technical and vocational education through knowledge of the historical constraints in Katsina State. The results of the study will also serve as useful guide in the provision of equipment and facilities for technical and vocational schools in Katsina State. The findings of this study will be useful to the government of 
Katsina State by providing information on the staff strength of technical and vocational schools in terms of adequacy and competency.

The findings of this study will be beneficial to students and teachers of technical and vocational schools by identifying these problems and offering immediate and long term suggestions for tackling some of the problems. Finally, the results of this study will serve as a guide to school authorities and teachers regarding strategies for executing various educational policies, particularly that concerning technical and vocational education.

\section{METHODOLOGY}

The study was based on government approved Technical and Vocational Institutions in Nigeria, for convenience of data collection five (5) institutions in Katsina State were purposively chosen for the research. The institutions were: Katsina Craft Village, Government Technical College Mashi, Government Technical College Ingawa, Government Technical College Funtua, and Hassan Usman Katsina Polytechnic (Tech. Edu Dept.). The study was based on data, collected through one structured questionnaire from a representative sample of principals, teachers and workshop attendants of the above mention five 5 institutions of Katsina State. The total population was approximated to be 164 . Thirty percent $30 \%$ of this population was selected as sample size thus $(\mathrm{N}=50)$. Fifty 50 questionnaires were administered through email with the help of research assistant who printed and distributed the questionnaires to the respective institutions. Ten 10 questionnaires were administered to each of the five 5 above mentioned institution. Thirty-seven 37 out of fifty 50 questionnaire were received, which translate to $74 \%$ rate of return. Chi-square Test and Weighted Average were used to analyze and interpret the data. Chi-square test was used in finding out whether or not the opinions of the respondents were statistically significant at 0.05 levels. The weighted averages (WA) were interpreted as: $4.5 \leq$ WA is "Strongly Agree"; $3.5 \leq 4.5 \mathrm{WA}$ is "Agree"; $2.5 \leq 3.5 \mathrm{WA}$ is "Undecided"; $1.5 \leq 2.5 \mathrm{WA}$ is "Disagree"; $0 \leq 1.5$ WA is "Strongly Disagree".

Following were the findings of the study:

\section{FINDINGS}

Majority of the respondents agreed that: The objective of Western education in Nigeria was to learn 3Rs (reading, writing and arithmetic). The lack of technical culture in Nigerian society resulted slow beginning and development of TVE. The early Nigerian Leaders did not give importance on developing TVE because they are literary oriented.

Table I Opinion of the Respondents Related To the Historical Constraints for Development of TVE in Nigeria

$(\mathbf{N}=37$ at $74 \%$ rate of return; $\boldsymbol{\alpha}=0.05)$ (Figures in the parenthesis indicate percentages)

\begin{tabular}{|c|c|c|c|c|c|c|c|c|c|}
\hline \multirow[b]{2}{*}{ No } & \multirow[b]{2}{*}{ Statements } & \multicolumn{5}{|c|}{ Level of Opinion } & \multirow[b]{2}{*}{ WA } & \multirow[b]{2}{*}{$\square^{2}$} & \multirow[b]{2}{*}{ 高 } \\
\hline & & 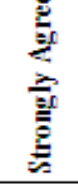 & 葛 & 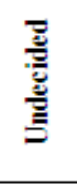 & 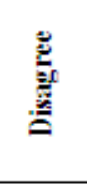 & 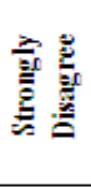 & & & \\
\hline 1 & $\begin{array}{l}\text { The objective of Western education in } \\
\text { Nigeria was to learn } 3 \mathrm{R} \text { (reading, writing } \\
\text { and arithmetic) }\end{array}$ & $\begin{array}{c}21 \\
56.8\end{array}$ & $\begin{array}{c}11 \\
29.7\end{array}$ & $\begin{array}{c}2 \\
5.4\end{array}$ & $\begin{array}{c}3 \\
8.1\end{array}$ & $\begin{array}{c}0 \\
0.0\end{array}$ & 4.4 & $\begin{array}{c}25.1 \\
6\end{array}$ & $\begin{array}{c}.00 \\
0\end{array}$ \\
\hline 2 & $\begin{array}{l}\text { Colonial government expected that } \\
\text { establishment of TVE, would speed up the } \\
\text { agitation for political Independence }\end{array}$ & $\begin{array}{c}8 \\
21.6\end{array}$ & $\begin{array}{c}12 \\
32.4\end{array}$ & $\begin{array}{c}7 \\
18.9\end{array}$ & $\begin{array}{c}8 \\
21.6\end{array}$ & $\begin{array}{c}2 \\
5.4\end{array}$ & 3.4 & 6.92 & $\begin{array}{c}.14 \\
0\end{array}$ \\
\hline 3 & $\begin{array}{l}\text { The negative impression about Vocational } \\
\text { education in Nigerian society was created } \\
\text { by the colonial leaders }\end{array}$ & $\begin{array}{c}8 \\
21.6\end{array}$ & $\begin{array}{c}6 \\
16.2\end{array}$ & $\begin{array}{c}7 \\
18.9\end{array}$ & $\begin{array}{c}11 \\
29.7\end{array}$ & $\begin{array}{c}5 \\
13.5\end{array}$ & 3.0 & 2.87 & $\begin{array}{c}.58 \\
1\end{array}$ \\
\hline 4 & $\begin{array}{l}\text { Lack of technical culture in Nigerian } \\
\text { society resulted slow beginning and } \\
\text { development of TVE }\end{array}$ & $\begin{array}{c}14 \\
37.8\end{array}$ & $\begin{array}{c}18 \\
48.6\end{array}$ & $\begin{array}{c}1 \\
2.7\end{array}$ & $\begin{array}{c}4 \\
10.8)\end{array}$ & $\begin{array}{c}0 \\
0.0\end{array}$ & 4.1 & $\begin{array}{c}21.0 \\
5\end{array}$ & $\begin{array}{c}.00 \\
0\end{array}$ \\
\hline 5 & $\begin{array}{l}\text { There was no need for skilled workers in } \\
1900 \text { s, therefore colonial masters } \\
\text { neglected TVE schools }\end{array}$ & $\begin{array}{c}7 \\
18.9\end{array}$ & $\begin{array}{c}10 \\
27.0\end{array}$ & $\begin{array}{c}5 \\
13.5\end{array}$ & $\begin{array}{c}12 \\
32.4\end{array}$ & $\begin{array}{c}3 \\
8.1\end{array}$ & 3.2 & 7.19 & $\begin{array}{c}.12 \\
6\end{array}$ \\
\hline 6 & $\begin{array}{l}\text { Early Nigerian Leaders did not give } \\
\text { importance on developing TVE because } \\
\text { they are literary oriented }\end{array}$ & $\begin{array}{c}8 \\
21.6\end{array}$ & $\begin{array}{c}17 \\
45.9\end{array}$ & $\begin{array}{c}1 \\
2.7\end{array}$ & $\begin{array}{c}6 \\
16.2\end{array}$ & $\begin{array}{c}5 \\
13.5\end{array}$ & 3.5 & $\begin{array}{c}19.0 \\
8\end{array}$ & $\begin{array}{c}.00 \\
1\end{array}$ \\
\hline 7 & $\begin{array}{l}\text { Upgrading of Technical Colleges to } \\
\text { Universities creates the present TVE } \\
\text { problems }\end{array}$ & $\begin{array}{c}4 \\
10.8\end{array}$ & $\begin{array}{c}8 \\
21.6\end{array}$ & $\begin{array}{c}7 \\
18.9\end{array}$ & $\begin{array}{c}13 \\
35.1\end{array}$ & $\begin{array}{c}5 \\
13.5\end{array}$ & 2.8 & 6.65 & $\begin{array}{c}.15 \\
6\end{array}$ \\
\hline
\end{tabular}


A Study of the Problems for Development of Technical and Vocational Education in Katsina State,

2. There is inadequate finance to buy modern equipment, materials for practical works. Inadequately equipped laboratory and workshop are among the reason for less development of TVE in Katsina state. The shortage of school workshops and laboratories to provide work experiences increase the problems of TVE development. The use of outdated equipment and facilities to train students worsen the problems. Inadequate teaching materials made the problems more rigid. The shortage of library and research facilities in TVE institutions is among the reason for making TVE less developed.

Table II Opinion of the Respondents Related To Lack of Equipment and Facilities TVE Institutions of Katsina State

$(\mathbf{N}=37$ at $74 \%$ rate of return; $\boldsymbol{\alpha}=0.05)$ (Figures in the parenthesis indicate percentages)

\begin{tabular}{|c|c|c|c|c|c|c|c|c|c|}
\hline \multirow[b]{2}{*}{ No } & \multirow[b]{2}{*}{ Statements } & \multicolumn{5}{|c|}{ Level of Opinion } & \multirow[b]{2}{*}{ WA } & \multirow[b]{2}{*}{$\square^{2}$} & \multirow[b]{2}{*}{ 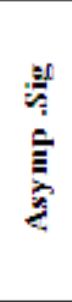 } \\
\hline & & 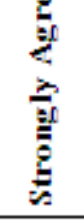 & $\underbrace{0}_{0}$ & 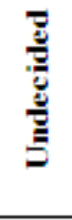 & $\frac{0}{0}$ & 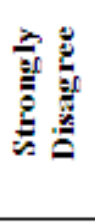 & & & \\
\hline 8 & $\begin{array}{l}\text { Inadequate finance to buy modern } \\
\text { equipment, materials for practical works }\end{array}$ & $\begin{array}{c}18 \\
48.6\end{array}$ & $\begin{array}{c}12 \\
32.4\end{array}$ & $\begin{array}{c}3 \\
8.1\end{array}$ & $\begin{array}{c}4 \\
10.8\end{array}$ & $\begin{array}{c}0 \\
0.0\end{array}$ & 4.2 & 16.29 & .001 \\
\hline 9 & $\begin{array}{l}\text { Inadequately equipped laboratory and } \\
\text { workshop }\end{array}$ & $\begin{array}{c}16 \\
43.2 \\
\end{array}$ & $\begin{array}{c}17 \\
45.9 \\
\end{array}$ & $\begin{array}{c}2 \\
5.4 \\
\end{array}$ & $\begin{array}{c}2 \\
5.4 \\
\end{array}$ & $\begin{array}{c}0 \\
0.0\end{array}$ & 4.3 & 22.78 & .000 \\
\hline 10 & $\begin{array}{l}\text { Shortage of school workshops and } \\
\text { laboratories to provide work experiences }\end{array}$ & $\begin{array}{c}14 \\
37.8\end{array}$ & $\begin{array}{c}19 \\
51.4\end{array}$ & $\begin{array}{c}3 \\
8.1\end{array}$ & $\begin{array}{c}1 \\
2.7\end{array}$ & $\begin{array}{c}0 \\
0.0\end{array}$ & 4.2 & 24.29 & .000 \\
\hline 11 & $\begin{array}{l}\text { Use of outdated equipment and facilities to } \\
\text { train students }\end{array}$ & $\begin{array}{c}17 \\
45.9 \\
\end{array}$ & $\begin{array}{c}13 \\
35.1 \\
\end{array}$ & $\begin{array}{c}5 \\
13.5 \\
\end{array}$ & $\begin{array}{c}2 \\
5.4 \\
\end{array}$ & $\begin{array}{c}0 \\
0.0 \\
\end{array}$ & 4.2 & 15.65 & .001 \\
\hline 12 & Inadequate teaching materials & $\begin{array}{c}17 \\
45.9 \\
\end{array}$ & $\begin{array}{c}13 \\
35.1 \\
\end{array}$ & $\begin{array}{c}4 \\
10.8 \\
\end{array}$ & $\begin{array}{c}2 \\
5.4 \\
\end{array}$ & $\begin{array}{c}1 \\
2.7 \\
\end{array}$ & 4.2 & 27.73 & .000 \\
\hline 13 & $\begin{array}{l}\text { Shortage of library and research facilities in } \\
\text { TVE institutions }\end{array}$ & $\begin{array}{c}16 \\
43.2 \\
\end{array}$ & $\begin{array}{c}12 \\
32.4\end{array}$ & $\begin{array}{c}6 \\
16.2\end{array}$ & $\begin{array}{c}2 \\
5.4\end{array}$ & $\begin{array}{c}1 \\
2.7 \\
\end{array}$ & 4.1 & 22.59 & .000 \\
\hline
\end{tabular}

3. There is inadequate number of Teachers in training institutions. There are less competent Instructors in training institutions. The Lack of in-service programme for Technical Teachers to upgrade their skills made worsen the problems of TVE. Poor salaries and incentives for Technical Teachers contribute to the problems of TVE development in Katsina state.

Table III Opinion of the Respondents Related To the Inadequate and Incompetent Technical Teachers in Katsina State

$(\mathbf{N}=37$ at $74 \%$ rate of return; $\boldsymbol{\alpha}=0.05)$ (Figures in the parenthesis indicate percentages)

\begin{tabular}{|c|c|c|c|c|c|c|c|c|c|}
\hline \multirow[b]{2}{*}{ No } & \multirow[b]{2}{*}{ Statements } & \multicolumn{5}{|c|}{ Level of Opinion } & \multirow[b]{2}{*}{ WA } & \multirow[b]{2}{*}{$\square^{2}$} & \multirow{2}{*}{$\frac{10}{3}$} \\
\hline & & 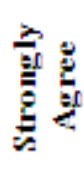 & 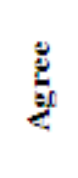 & 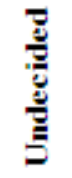 & 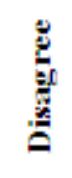 & 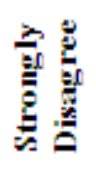 & & & \\
\hline 14 & $\begin{array}{l}\text { Inadequate number of teachers in training } \\
\text { institutions }\end{array}$ & $\begin{array}{c}13 \\
35.1\end{array}$ & $\begin{array}{c}20 \\
54.1\end{array}$ & $\begin{array}{c}2 \\
5.4\end{array}$ & $\begin{array}{c}1 \\
2.7\end{array}$ & $\begin{array}{c}1 \\
2.7\end{array}$ & 4.2 & $\begin{array}{c}40.7 \\
0\end{array}$ & .000 \\
\hline 15 & $\begin{array}{l}\text { Less competent Instructors in training } \\
\text { institutions }\end{array}$ & $\begin{array}{c}9 \\
24.3 \\
\end{array}$ & $\begin{array}{c}18 \\
48.6 \\
\end{array}$ & $\begin{array}{c}4 \\
10.8 \\
\end{array}$ & $\begin{array}{c}5 \\
13.5 \\
\end{array}$ & $\begin{array}{c}1 \\
2.7 \\
\end{array}$ & 3.8 & $\begin{array}{c}23.4 \\
1\end{array}$ & .000 \\
\hline 16 & $\begin{array}{l}\text { Lack of in-service programme for TVE } \\
\text { teachers to upgrade their skills }\end{array}$ & $\begin{array}{c}8 \\
21.6 \\
\end{array}$ & $\begin{array}{c}16 \\
43.2 \\
\end{array}$ & $\begin{array}{c}5 \\
13.5 \\
\end{array}$ & $\begin{array}{c}7 \\
18.9 \\
\end{array}$ & $\begin{array}{c}1 \\
2.7 \\
\end{array}$ & 3.6 & $\begin{array}{c}16.3 \\
8\end{array}$ & .003 \\
\hline 17 & $\begin{array}{l}\text { Poor salaries and incentives for the technical } \\
\text { teachers }\end{array}$ & $\begin{array}{c}9 \\
24.3\end{array}$ & $\begin{array}{c}21 \\
56.8\end{array}$ & $\begin{array}{c}3 \\
8.1\end{array}$ & $\begin{array}{c}3 \\
8.1\end{array}$ & $\begin{array}{c}1 \\
2.7\end{array}$ & 3.9 & $\begin{array}{c}36.1 \\
2\end{array}$ & .000 \\
\hline
\end{tabular}


A Study of the Problems for Development of Technical and Vocational Education in Katsina State,

4. The students are not motivated to go for Technical Education. There is production of incompetent graduates. The students cannot compete the challenges in workplaces.

Table IV Opinion of the Respondents Related To the TVE Problems on Students of Katsina State $(\mathbf{N}=37$ at $74 \%$ rate of return; $\boldsymbol{\alpha}=0.05$ ) (Figures in the parenthesis indicate percentages)

\begin{tabular}{|c|c|c|c|c|c|c|c|c|c|}
\hline \multirow[b]{2}{*}{ No } & \multirow[b]{2}{*}{ Statements } & \multicolumn{5}{|c|}{ Level of Opinion } & \multirow[b]{2}{*}{ WA } & \multirow[b]{2}{*}{$\square^{2}$} & \multirow[b]{2}{*}{ 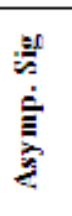 } \\
\hline & & 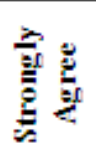 & 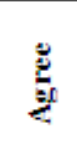 & 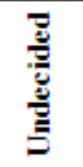 & 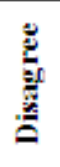 & 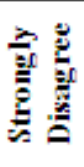 & & & \\
\hline 18 & $\begin{array}{l}\text { Students are not motivated to go for } \\
\text { Technical Education }\end{array}$ & $\begin{array}{c}20 \\
54.1\end{array}$ & $\begin{array}{c}14 \\
37.8\end{array}$ & $\begin{array}{c}2 \\
5.4\end{array}$ & $\begin{array}{c}1 \\
2.7\end{array}$ & $\begin{array}{c}0 \\
0.0\end{array}$ & 4.4 & $\begin{array}{c}27.9 \\
7\end{array}$ & .000 \\
\hline 19 & Production of incompetent graduates & $\begin{array}{c}11 \\
29.7\end{array}$ & $\begin{array}{c}19 \\
51.4\end{array}$ & $\begin{array}{c}4 \\
10.8\end{array}$ & $\begin{array}{c}0 \\
0.0\end{array}$ & $\begin{array}{c}3 \\
8.1\end{array}$ & 3.9 & $\begin{array}{c}17.8 \\
1\end{array}$ & .000 \\
\hline 20 & $\begin{array}{l}\text { Students cannot compete the challenges in } \\
\text { workplaces }\end{array}$ & $\begin{array}{c}8 \\
21.6\end{array}$ & $\begin{array}{c}20 \\
54.1\end{array}$ & $\begin{array}{c}6 \\
16.2\end{array}$ & $\begin{array}{c}3 \\
8.1\end{array}$ & $\begin{array}{c}0 \\
0.0\end{array}$ & 3.9 & $\begin{array}{c}18.0 \\
3\end{array}$ & .000 \\
\hline
\end{tabular}

5. There was inadequate numbers of expert in designing TVE curriculum. There is lack of involvement of TVE educators in educational planning. The Technical Teachers are not employed to teach in TVE Institutions. Lack of separate Ministry of Technical and Vocational Education made it more difficult for the TVE to develop effectively. There is unawareness of TVE for economic development of the Country. There is negligence of TVE Institutions to get feedback about their students after graduation. There is less emphasis on human development.

Table V The Responses Related To the Trends in Policymaking, Planning \& Implementation of TVE Programmes

$(\mathbf{N}=37$ at $74 \%$ rate of return; $\boldsymbol{\alpha}=0.05$ ) (Figures in the parenthesis indicate percentages)

\begin{tabular}{|c|c|c|c|c|c|c|c|c|c|}
\hline \multirow[b]{2}{*}{ No } & \multirow[b]{2}{*}{ Statements } & \multicolumn{5}{|c|}{ Level of Opinion } & \multirow[b]{2}{*}{ WA } & \multirow[b]{2}{*}{$\square^{2}$} & \multirow[b]{2}{*}{$\begin{array}{l}\text { Asy } \\
\mathrm{mp} \\
\text { Sig }\end{array}$} \\
\hline & & 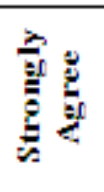 & 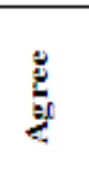 & 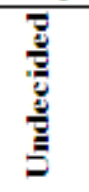 & $\frac{8}{6}$ & 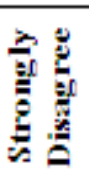 & & & \\
\hline 21 & $\begin{array}{l}\text { Inadequate numbers of expert in designing } \\
\text { TVE curriculum }\end{array}$ & $\begin{array}{c}11 \\
29.7\end{array}$ & $\begin{array}{c}17 \\
45.9\end{array}$ & $\begin{array}{c}4 \\
10.8\end{array}$ & $\begin{array}{c}3 \\
8.1\end{array}$ & $\begin{array}{c}2 \\
5.4\end{array}$ & 3.9 & $\begin{array}{c}22.3 \\
2\end{array}$ & .000 \\
\hline 22 & $\begin{array}{l}\text { Lack of involvement of TVE Educators in } \\
\text { educational planning }\end{array}$ & $\begin{array}{c}11 \\
29.7\end{array}$ & $\begin{array}{c}19 \\
51.4\end{array}$ & $\begin{array}{c}4 \\
10.8\end{array}$ & $\begin{array}{c}2 \\
5.4\end{array}$ & $\begin{array}{c}1 \\
2.7\end{array}$ & 4.0 & $\begin{array}{c}30.9 \\
7\end{array}$ & .000 \\
\hline 23 & $\begin{array}{l}\text { Technical teachers are not employed to } \\
\text { teach in TVE Institutions }\end{array}$ & $\begin{array}{c}9 \\
24.3\end{array}$ & $\begin{array}{c}15 \\
40.5\end{array}$ & $\begin{array}{c}4 \\
10.8\end{array}$ & $\begin{array}{c}8 \\
21.6\end{array}$ & $\begin{array}{c}1 \\
2.7\end{array}$ & 3.6 & $\begin{array}{c}15.2 \\
9\end{array}$ & .004 \\
\hline 24 & $\begin{array}{l}\text { Lack of separate Ministry of Technical and } \\
\text { Vocational Education }\end{array}$ & $\begin{array}{c}7 \\
18.9\end{array}$ & $\begin{array}{c}20 \\
54.1\end{array}$ & $\begin{array}{c}4 \\
10.8\end{array}$ & $\begin{array}{c}4 \\
10.8\end{array}$ & $\begin{array}{c}2 \\
5.4\end{array}$ & 3.7 & $\begin{array}{c}28.5 \\
4\end{array}$ & .000 \\
\hline 25 & $\begin{array}{l}\text { Unawareness of TVE for Economic } \\
\text { Development of the Country }\end{array}$ & $\begin{array}{c}13 \\
35.1 \\
\end{array}$ & $\begin{array}{c}17 \\
45.9 \\
\end{array}$ & $\begin{array}{c}3 \\
8.1 \\
\end{array}$ & $\begin{array}{c}3 \\
8.1 \\
\end{array}$ & $\begin{array}{c}1 \\
2.7 \\
\end{array}$ & 4.0 & $\begin{array}{c}27.4 \\
6\end{array}$ & .000 \\
\hline 26 & $\begin{array}{l}\text { Negligence of Institutions to get feedback } \\
\text { about their students after graduation }\end{array}$ & $\begin{array}{c}10 \\
27.0\end{array}$ & $\begin{array}{c}21 \\
56.8\end{array}$ & $\begin{array}{c}3 \\
8.1 \\
\end{array}$ & $\begin{array}{c}3 \\
8.1\end{array}$ & $\begin{array}{c}0 \\
0.0\end{array}$ & 4.0 & $\begin{array}{c}23.4 \\
3\end{array}$ & .000 \\
\hline 27 & Less emphasis on human development & $\begin{array}{c}11 \\
29.7\end{array}$ & $\begin{array}{c}15 \\
40.5\end{array}$ & $\begin{array}{c}9 \\
24.3\end{array}$ & $\begin{array}{c}2 \\
5.4\end{array}$ & $\begin{array}{c}0 \\
0.0\end{array}$ & 3.9 & 9.59 & .002 \\
\hline
\end{tabular}

6. By assigning experts in designing TVE Curriculum government can assist in encouraging development TVE. By adding of welfare and incentives for technical teachers, government can encourage development of TVE. Moreover, the majority of the respondents agreed that: By establishment of separate Technical and Vocational Education Ministry, it will develop rapidly. By establishment of more technical institutions government can assist in encouraging the development TVE. 
Table VI Opinion of the Respondents Related To the Measures That How Government Could Tackle the Problems of TVE

( $\mathbf{N}=37$ at $74 \%$ rate of return; $\boldsymbol{\alpha}=0.05)$ (Figures in the parenthesis indicate percentages)

\begin{tabular}{|c|c|c|c|c|c|c|c|c|c|}
\hline \multirow[b]{2}{*}{ No } & \multirow[b]{2}{*}{ Statements } & \multicolumn{5}{|c|}{ Level of Opinion } & \multirow[b]{2}{*}{ WA } & \multirow[b]{2}{*}{$\square^{2}$} & \multirow{2}{*}{ 竞 } \\
\hline & & 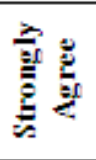 & 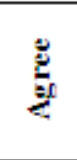 & 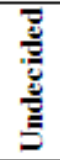 & 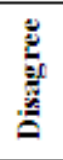 & 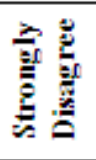 & & & \\
\hline 28 & $\begin{array}{l}\text { Establishment of separate Technical and } \\
\text { Vocational Education Ministry }\end{array}$ & $\begin{array}{c}19 \\
51.4\end{array}$ & $\begin{array}{c}15 \\
40.5\end{array}$ & $\begin{array}{c}2 \\
5.4\end{array}$ & $\begin{array}{c}1 \\
2.7\end{array}$ & $\begin{array}{c}0 \\
0.0\end{array}$ & 4.4 & $\begin{array}{c}26.8 \\
9\end{array}$ & .000 \\
\hline 29 & $\begin{array}{l}\text { Assigning Experts In designing TVE } \\
\text { Curriculum }\end{array}$ & $\begin{array}{c}22 \\
59.5\end{array}$ & $\begin{array}{c}14 \\
37.8 \\
\end{array}$ & $\begin{array}{c}1 \\
2.7\end{array}$ & $\begin{array}{c}0 \\
0.0\end{array}$ & $\begin{array}{c}0 \\
0.0\end{array}$ & 4.6 & $\begin{array}{c}18.2 \\
2\end{array}$ & .000 \\
\hline 30 & $\begin{array}{l}\text { Addition of welfare and incentives for } \\
\text { technical teachers }\end{array}$ & $\begin{array}{c}19 \\
51.4\end{array}$ & $\begin{array}{c}17 \\
45.9\end{array}$ & $\begin{array}{c}1 \\
2.7\end{array}$ & $\begin{array}{c}0 \\
0.0\end{array}$ & $\begin{array}{c}0 \\
0.0\end{array}$ & 4.5 & $\begin{array}{c}15.7 \\
8\end{array}$ & .000 \\
\hline 31 & $\begin{array}{l}\text { Establishment of more technical } \\
\text { institutions }\end{array}$ & $\begin{array}{c}15 \\
40.5\end{array}$ & $\begin{array}{c}18 \\
48.6\end{array}$ & $\begin{array}{c}1 \\
2.7\end{array}$ & $\begin{array}{c}3 \\
8.1\end{array}$ & $\begin{array}{c}0 \\
0.0\end{array}$ & 4.2 & $\begin{array}{c}23.4 \\
3\end{array}$ & .000 \\
\hline
\end{tabular}

\section{DISCUSSION}

This study found that, there are some historical reasons for the slow development of technical and vocational education in Nigeria which are still shaping the present, such reasons are found from the main objectives of western education in Nigeria which over-emphasized ability to read and write only, which ultimately resulted in today's lack of technical culture in the Nigerian society. Umunadi (2007) poised that, there is lack of awareness of vocational and technical education VTE in the country. The findings of this study revealed that, "early Nigerian leaders did not give importance on technical and vocational education because they too were not technically oriented'. In addition, the findings of this study revealed that, there was undecided response, whether 'the colonial government expected the establishment of technical and vocational education would speed up the agitation for political Independence' and whether, 'the colonial leaders are responsible for creating the negative impression about vocational education in Nigerian society'. Whether 'there was no need for skilled workers in 1900s, which is why colonial masters' neglected TVE schools' is also undecided.

This study revealed that 'there is inadequate finance to buy modern equipment and materials for practical works' there is 'inadequately equipped laboratory and workshop'. There is 'shortage of school workshops and laboratories to provide work experiences' there 'are outdated equipment and facilities used to train students'. There are 'inadequate teaching materials in the schools/colleges'. Finally, there is shortage of library and research facilities in the schools for the teachers and students. It is evident that inadequate provision of equipment and facilities is due to low level of funding TVE institutions in Nigeria (Alamu, 2011; Atsumbe et al., 2012). The findings of this study have shown that, there is 'inadequate number of teachers and 'less number of competent technical Teachers/Instructors' in the training institutions. It also revealed that, 'the lacks of inservice programme for Technical Teachers to upgrade their skills deteriorate problem'. And there is 'Poor salaries and incentives for Technical Teachers' in technical and vocational schools in Nigeria. According to Okorie (2001), the teachers are incompetent to operate and use the equipment to train the students, thus equipment were as new as when they imported and some were in storage facilities.

The study also discovered that, 'the majority of the students are not motivated to go for Technical Education' and there is 'production of incompetent graduates from technical and vocational schools'. Finally, it was revealed that, 'the graduated students could not compete with the challenges in workplaces; as Nkokelonye (2008) \& Kennedy (2010) stated, many students who have pursued TVE in Nigeria often find themselves with general or theoretical knowledge that does little to prepare them for the actual tasks or skills they are encountering on their job interviews. Related to the Trends in Policy-making, Planning and Implementation of TVE Programmes in Nigeria. This study revealed that, "there was inadequate numbers of expert in designing TVE curriculum' there was 'lack of involvement of TVE Educators in educational planning'. According Finch \& Crunkilton, (1999) they noted that, the character of any curriculum is determined by the personalities and policies behind it. Therefore, to come up with a dynamic curriculum that would be responsive to the needs of the changing national economy, the issue of the right participant in the formulation of such a curriculum policy and design must be tackled.

In addition, 'Technical Teachers were not employed to teach in technical and vocational institutions', 'the absence of independent or separate Ministry of Technical and Vocational Education made it hard for the TVE to develop effectively'. It was also revealed that, there is 'lack of awareness of TVE for economic development of the country', there is 'negligence of TVE Institutions to get feedback about their students after 
graduation'. Moreover, there is 'Less emphasis on human development' in the country. According to Uwaifo (2009), the lack of curriculum experts in industrial technical education is visible in the curricular for industrial technical and vocational education in Nigeria as the course is more theoretical than practical in the order of other general/liberal education. For suggestions on how Government can assist for improvement of TVE in the state. The respondents strongly agreed that, government could assist in development TVE by assigning TVET Experts in designing and evaluating of TVE Curriculum, by adding welfare and incentives for technical teachers, government can encourage development of TVE. The respondents also agreed that, by creating a separate Technical and Vocational Education Ministry, TVET would develop rapidly. Finally, it is accepted notion that by establishing of more technical institutions government can assist in development a technical and vocational education in the state.

\section{CONCLUSION AND RECOMMENDATION}

In the light of the findings and conclusions, the following recommendations were made: The emphasis of reading, writing \& arithmetic should be modified because this alone cannot help any county to realize its full potential. Human development through skills training should be emphasis. Campaign, which would motivate the Nigerian societies about technical and vocational education, should be frequently organized. The current Nigerian leaders should learn from the previous regimes; that, it is lack of human development through technical and vocational education hinders the development of Nigeria for the last fifty-three years after independence. All colonial leaders faults can be corrected efficiently and effectively though dedicative work. Government should increase the current allocated funds of technical and vocation schools/colleges and higher institutions for qualitative education, as most of the technical or vocational schools are reported to have inadequately equipped laboratories and workshops; they have outdated equipment and facilities to train their students, inadequate teaching materials, the shortages of school workshops, laboratories, and library and research facilities.

It is generally acceptable notion that there is inadequate number of technical teachers in the technical or vocation training schools. Government can tackle this problem by opening new programs in some current operating institutions, which would train more teachers that are technical. Furthermore, lack of in-service prorammes for technical teachers should be address by organizing seminar and workshops etc, so that the current technical teachers can update/upgrade their knowledge and skills to pace with current dynamic technology. Finally, salaries and incentives should be increase in order to motivate Technical Teachers to discharge their duties effectively. The number of unemployed youth across the country can be reduced by increasing the skills in hands of employees, employer often complaint about lack of skills of candidates is reason for not employing them but not their qualification. Therefore, government should ensure that students are motivated to acquire technical skills not only degree certificates, this can be achieve through media and some vocational youth organizations. Furthermore, government should take full responsibilities for the quality of technical or vocational graduates and make sure that they can compete with the challenges they may face in their workplaces.

An effective and efficient decision can only achieve if there is availability of reliable information, and the reliable information could be secured from expert in that field. Therefore excluding technical and vocational educators and expert in educational planning, curriculum design and development may lead to improper decisions making. In addition, technical teachers should be employed to teach in technical or vocational schools, as they may know better way to impart the technical skills to the students. Insufficient budget may longer be a problem if separate Ministry of technical and vocational education is created. Unawareness of technical and vocational education can be decrease through media campaign. Finally, technical and vocational schools should implement reliable feedback system to know about how their graduates are coping in their workplaces. To ensure a high-quality product, diagrams and lettering MUST be either computer-drafted or drawn using India ink. Figure captions appear below the figure, are flush left, and are in lower case letters. When referring to a figure in the body of the text, the abbreviation "Fig." is used. Figures should be numbered in the order they appear in the text. Table captions appear centered above the table in upper and lower case letters. When referring to a table in the text, no abbreviation is used and "Table" is capitalized.

\section{REFERENCES}

[1] Alamu, S. A. (2011). The State of Science and Technology Infrastructure in Secondary Schools in Nigeria. Journal of Educational and Social Research. Vol. 2 (8) October 2011 p 56-66

[2] Atsumbe, B.N, Emmanuel Raymond, Igwe, C.O1 \& Atsumbe, J. A(2012). Repositioning Vocational and Technical Education for Effective Manpower Production in Nigeria: IOSR Journal of Mechanical and Civil Engineering (IOSRJMCE) I( 4), 01-06

[3] Dike, V. E. (2009). Addressing Youth Unemployment and Poverty in Nigeria: A call for Action, Not Rhetoric". Journal of Sustainable Development in Africa,11(3), 129-151. 
[4] Edukugho, E. (2011). Nigeria: Rectors Meet, Tackle Challenges Facing Technological Education. Vanguard 29 September, 2011

[5] Fafunwa, A.B. (1974). A History of Nigerian Higher Education, Lagos Macmillan Publishers.

[6] Finch, C. R., \& Crunkilton, J. R. (1999). Curriculum development in vocational and technical education. planning, content, and implementation. Allyn and Bacon, 160 Gould Street, Needham Heights, MA 02494.

[7] FRN Federal Republic of Nigeria (2004). National Policy on Education (Revised). Lagos, NERDC Press, Yaba.

[8] Henry O. Owolabi. (2003). "Technical and Vocational Education in Nigeria” Emola-Jay Communications Inc. (pp 107-116).

[9] Ibukun W. O (2010). Nigeria's National Policy on Education and the University Curriculum in History: Implication for Nation Building. Journal of Education and Practice Vol 1, No 2, 2010

[10] ILO (2011). Global Employment Trends for Youth: 2011 update. Geneva: International Labour Office.

[11] ILO (2012). Global Employment Trends: 2012: Preventing a deeper jobs crises; Geneva: International Labour Office.

[12] Kennedy E. Umunadi.(2010). Acquisition of Skills and Competencies by Technical Education Teachers as Instrument for National Growth in Nigeria, Journal of Qualitative Education, Volume 6 No. 1 May,

[13] Kennedy Umunadi, E (2012). Empowering Vocational and Technical Education Teachers and Students Through Curriculum Implementation. Reforms for Attainment of Millenium Development Goals, Journal of Educational and Social Research Vol. 2 (7), p 158-166

[14] Muhammad, B. A. (2012). Integrating e-learning in Technical and Vocational Education: A Technical Review. International Journal of Academic Research in Business and Social Sciences: Vol. 2, No. 5, May 2012.

[15] Nkokelonye, C.N. (2008). Skills and competencies needed by education history graduates for higher production and productivity in Nworgu B.G. (Ed). A Reform Agenda: Educational Reforms and the Attainment of Millennium Development Goals: The Nigerian Experience. Nsukka: University Trust publishers.

[16] Okorie, J. U. (2001). Vocational Industrial Education. Bauchi League of Researcher in Nigeria.

[17] Osuala, E.C. (1981). Foundation of Vocational Education Behavioural Objectives Approach.

[18] Umunadi, E.K. (2007). Effect of teacher-constructed circuits on student's performance in basic electricity and electronics in technical colleges in Nigeria. Unpublished PhD Thesis UNN.

[19] UN (2012). World Youth Report Geneva: United Nations.

[20] UN/DESA (2011). World Economic Situation and Prospects 2012: Global Economic Outlook, New York: United Nations.

[21] UNESCO (2005). Recommendation Concerning Technical and Vocational Education: Journal of Technical Education, p.07

[22] Uwaifo V.O. (2009). Technical education and its challenges in Nigeria in the 21st Century: International NGO Journal Vol. 5(2), pp. 040-044, Available online at http:// www.academicjournals.org/ingoj 